\title{
A Nimble Footing on the Coals: Tin Ujević, Lyricist: Some English Perspectives
}

The Croatian poet Augustin (Tin) Ujević (1891-1955) is one of the finest Southern Slav lyric poets and one of the great poets of Europe in the first half of the 20th century. What follows is a sketch of some of the qualities of his lyrical poems, from the particular perspective of an English poet who has translated some of them. My intention is to introduce a poet who, so far, has scarcely been registered at all in the English-speaking world ${ }^{[1]}$ by prefacing translations of twelve poems. The idea here is to pick out strands and suggest possible entry points. I also want to explore some of the reasons why I think he merits the appellation 'great poet', one that is easy enough to bestow, perhaps too easy, but less so to justify.

The procedure I shall adopt in the notes that follow will be suggestive and glancing rather than direct and expository. While the notes will of course move into and around some of Tin's lyrical poems and suggest paths for critical analysis and interpretative discussion, they will follow zigzagging forays and tangential meanderings, some of which will spiral back on themselves, as well as paratactic jumps and juxtapositions with other reference points and contexts, especially in the Anglophone literary tradition, rather than any kind of straightforward march towards a preformulated thesis. The act of writing this involves discovery for me too. I learn by going where I have to go (Roethke 104).

While Tin Ujević's poems are hardly known in English, they are loved in his native Croatia and throughout former Yugoslavia. I say ‘loved’ advisedly. I don't mean just admired or respected. At least until the break-up of the Yugoslav Federation, many of his lyrics were known by heart and quoted by people all over the country, even those who weren't particularly literary, in much the same way as some of W. B. Yeats's early poems, like 'The Lake Isle of Innisfree', 'He Wishes for the Cloths of Heaven' and 'Down by the Salley Gardens, ${ }^{[2]}$ are known and quoted all over Ireland 
and the UK. This is mainly because people brought up in the various Yugoslav republics learned some of Tin's poems at school. What is more, the sincerity of affection for him as a poet and as a man is evident even today in South-Slavic countries, especially in the tendency still to refer to him by his pet-name: Tin - a practice I shall follow here because of my own affection for his writings. And just as the topics of his poems are intimate, and his poetic personality comes across as endearing and sympathetic, so readers in his own language experience and share an intimate response to his poems and feel that they 'know' the 'real' Tin too. "Not a line does not flow out of genuine feeling," writes the Ch'ing editor Yang Lun of the great Tang dynasty poet Du Fu. His poetry "greatly surpasses others precisely in its sincerity," writes the Sung Buddhist monk HuiHung (Chou 197). No less could be claimed for Tin, even though it would be hard for a lyric poet in any language to match the achievement of Du Fu.

Such a popular response as this asks to be unravelled, especially when the character of the man is so conflated with his dominant poetic persona. When I went to live in former Yugoslavia in 1987, the poems of Tin's that I first came across, as might be expected, were his most anthologised pieces. In Split, 1987, Daša Marić asked me to try translating some of these best-known poems, and because my Croatian at that time - or rather, my Serbo-Croat - was a beginner's, she helped me by making literal versions, which we worked from together. Later, in Belgrade and then in Cambridge, I became more or less proficient enough to translate several more poems alone.

Tin's art is delicate, highly crafted, akin to that of filigree. Translation of a poet as intricate as he is sometimes works, sometimes doesn't. You try things out, one after another, you keep your head down, you follow your nose, you fool around, you suddenly wake up in the middle of the night with a better alternative for a phrase running through your head, you turn the light on and scribble it down for fear of forgetting it, you recheck it next morning, you revise, you polish - and sometimes, if you're lucky, one or two poems do come out right.

Of course, I felt it at all times necessary to transmute Tin's form, in both the narrow and broad senses ${ }^{[3]}$ At the micro-level, his patterns of rhyme, rhythm, melopoeia and so on, and at the macro-level, his overall musicality and sense of number, measure and measurement, are integral to his poems and inseparable from their overall meaning - though number and measure of course 
come in at all other levels too. At any rate, without rendering all these elements, Tin's genius gets lost. 'Meaning' is in no way reducible to 'literal meaning'.

Between 1987 and 1991, when I lived in former Yugoslavia, translating these poems was part of my introduction to the language then known as Serbo-Croat. In Monica Partridge's Serbo-Croat grammar, which I was working through at the time, I even found one of Tin's most famous poems, 'Svakidašnja jadikovka' ('Daily Lament'), quoted as a reading exercise for the ljekavian (ijekavski) variant of Štokavian (štokavski), a form of Croatian (Partridge 66). Since the conflicts of the 1990s and the splintering and collapse of the Yugoslav Federation, the appellation 'Serbo-Croat' is no longer 'politically correct', whether according to the precise meaning of that expression or in any of its colloquial connotations. There has been too much bitterness, on all sides, to allow whatever communal good-will that was once inherent in that composite term to survive. War and politics aside, however, the linguistic point that needs reiterating for English-speaking readers is that Tin's work is entirely approachable and understandable by readers throughout Croatia, Bosnia, Herzegovina, Montenegro and Serbia, just as it always has been.

Between 1987 and 1991, I took part in poetry festivals and gave readings all over Yugoslavia. In Croatia, Serbia and Montenegro, as well as in Macedonia and Slovenia (which have entirely distinct languages), whenever I read Daša Marić's and my English translations of Tin's poems at these literary events - always of course alongside deliveries of the original versions, whether by friends, students, fellow poets or actors - I had plenty of first-hand opportunities to experience the full extent of his popularity. On these occasions, it was the immediacy and depth of the connection that audiences made with Tin's poems which unleashed the fullest pleasure, together with listeners' delight that some of his poems had been translated into English.

Despite - yet also because of - his popularity in the South Slavic zone of language and culture, I do think there is a genuine 'difficulty' in understanding Tin's uniqueness as a poet, as distinct from simply 'responding' to his poems with readiness and sincerity. For the more questions that are asked of the poems, the more what at first seemed transparent and lucid on their surfaces seems either to mist over or to refract a bewildering array of facets. And while there are of course plenty of available pointers into the 'interiors' of the poems, these are not exactly arrow-like, but tend to be so intricately plaited, or criss-crossed, that picking out one from another isn't that easy. Then again, 
once one has passed through the poems' surfaces into their depths, one is inevitably confronted by a specific and intrinsic literary 'problem': how to read - and configure - Tin's melancholia, which is sometimes discomfiting and can at times arouse a sense of embarrassment ${ }^{[4]}$ In any reading of his lyrics, this issue can scarcely fail to resonate, as a sort of background hum or basso drone. Inevitably, this difficulty will surface in what follows and require at least occasional attention. And if 'embarrassment' is the deep 'ground', the tenderer question of 'sincerity', which sometimes reaches a higher, shriller pitch, will also need occasional focus. Both these issues need to be contextualised, too, within the larger question of how a reading of 'beauty' is approached - or not approached - in post-Romantic poetry, including works being written and published today.

Born in 1891 in Vrgorac, a small town in the Dalmatian hinterland, Tin grew up in Imotski and Makarska, and attended the classical gymnasium in Split. His language and sensibility are indelibly marked by the rugged beauty of the Dalmatian littoral, that narrow, sunbaked, rocky coastline, backed by mountains, facing out on the Adriatic sea and the islands of Hvar, Brač and Korčula. So, for example, in 'Slaboća' ('Frailty'), he writes longingly of "našem plavom, plavom valu, /... našem bijelom , bijelom žalu" (translated as "the waves of our blue blue sea, / and white pebbles."). Though Tin's major achievement is as a lyricist, his oeuvre is much broader than lyric alone. He was a writer of profound and discerning intellect, broad and capacious interests, inquisitive appetite and eclectic range. His Collected Works number sixteen volumes, including poems in many forms, from free verse to the Whitmanesque verset, prose-poems, essays, criticism, aphorisms, a book of thoughts and jottings compiled into a kind of personal 'encyclopaedia', and translations of fiction, plays and poems by authors as various as Poe, Whitman, Verhaeren, Rimbaud, Gide, Conrad, Meredith and Benvenuto Cellini, among others.

Tin spent many years living in Zagreb, as well as periods in Split, Sarajevo, Mostar, and Belgrade. In his youth, his involvement in the Pan-Slavic movement to establish a Yugoslav state earned him the disapprobation of the Austro-Hungarian authorities and the close attention of their police. From 1913 to 1919, he lived in exile in Paris (Montparnasse), where he mingled in the same milieu as other radical writers, artists and intellectuals from Croatia, Bosnia and Serbia, as well as such figures as Picasso, Modigliani, Cocteau, Ehrenburg, and d'Annunzio. Throughout his life, he lived simply. Well-known as an anarchic bohemian, he was a frequenter of bars and cafés, and always 
poor. Typical photos show him wearing a battered and ramshackle trilby cocked at a lopsided angle. Affectionate anecdotes about him abound, whether true or apocryphal, like the one I heard about him from poet-friends in Kragujevac, Šumadija, the Serbian heartland. It goes like this: Tin is sitting in a bar with friends, blindfold, tasting wines from all over Yugoslavia and identifying them. He sips half a dozen samples in turn, swirls each one around his mouth, and names all of them in quick succession without a single mistake. Then someone thrusts a glass of water into his hands. He takes a slurp. "No, I don't recognize that one," he says. Other stories aren't so salubrious. There's one about him taking off his hat, picking two fleas out of his hair, and inviting his friends to place bets on a race between them across a café table. Apparently, he spent five years in the French Foreign Legion, though I haven't yet found out when or where he served.

Tin's most celebrated lyrics are those in the collection Kolajna (The Necklace) (1926), the tour-deforce 'Svakidašnja jadikovka' ('Daily Lament') as well as several other poems that first appeared with it in Lelek sebra (Cry of a Slave) (1920). These are the pieces I shall concentrate on in the following notes, because they are the poems I have translated and know best. These poems are anthology classics, and in them Tin achieves an exquisite finesse of craft. In Croatian, at least a dozen of them are no less than perfect. They stand as models of lyrical 'purity', do so unequivocally for all time, whatever the vagaries of literary fashion.

First, then, the surfaces. Curiously, even though these poems were published after the First World War, their prevailing motifs - loss, longing, loneliness, nostalgia and regret - seem at face value almost entirely conventional and derivative, as do their traditionally formal patternings, especially to any reader familiar with the poetry of the French Symbolists and the English Victorians, or the paintings of the English Pre-Raphaelites and exponents of 'Art for Art's Sake'. Indeed, for some English-speaking readers, these poems by Tin may have an altogether too familiar fin-de-siecle flavour. In this context, incidentally, it may seem surprising to discover that Tin read Ezra Pound. So far as I know, there is no indication that he read T. S. Eliot. It would be interesting to find out whether he did.

It is probably accurate to say that Tin's writing straddles the fin-de-siecle and early modernism. In tones of flamboyant enthusiasm, the Wikipedia entry for him confirms this view: "Ujević spent his turbulent Lehrjahre in the Zagreb bohemian milieu, in the circle of the central figure of Croatian 
early modernism, the revered and slandered doyen of aestheticism, Antun Gustav Matoš. ${ }^{[6]}$ In an age such as ours, when some aspects of Tin's kind of writing may tend to be undervalued, unvalued, regarded as 'effete' or 'decadent', or simply dismissed as 'dated', inevitably some readers will find Tin's lyrics not to their taste, even irritating, especially those who like their poetry rough-edged or 'experimental'. But only once his formal and thematic constraints have been accepted by the reader can it be recognised that, as a lyricist, Tin is unparagoned. It is the intense, clear personal voice that he brings to the convention, and what he does with and within it, the depths and resonances that he sounds in it, that are most rewarding.

Tin's poems of the 1920s are immediately approachable in their surface lucidity and simplicity. Every poem is interpretable as a formally composed container or vessel from which an interior feeling emerges. And if it is a truism that exploration and expression of subjectivity are part and parcel of all lyrical poetry, what particularly characterises Tin is that the feeling itself appears to be allowed 'out' and 'up' in the very instant of being felt; or, rather, it is released, simply and clearly, in the precise act of being apprehended. That is to say, it is 'expressed', or perhaps a better word would be 'ascribed', directly, with neither resistance nor hesitation, and certainly with no need of filtration through the kinds of self-irony, emotional reticence or linguistic gamesmanship that mark a good deal of modernist and postmodernist writing. There is artifice, to be sure, and it is of a high order: Tin is far too sophisticated a poet ever to be interpretable as a naif. Once (or, rather, if) this point has been accepted, it then becomes evident that his artifice operates so unobtrusively that it implies an effortless spontaneity and sincerity. At this level of reading, then, if there is an impression of transparency in Tin's lyrics, this becomes convincing and genuine thanks to his artifice, although as I hope to show, that is not necessarily all there is to it. Impressions can be beguiling and misleading.

From an English reader's perspective, my first suggestion is that in its direct expression of feeling, its melancholia, and its musicality, Tin's lyric poetry is reminiscent of Tennyson's In Memoriam (1850). Consider, then, the frankness and modesty of the following imagem ${ }^{7]}$ of the waterglass, with flowers in it, from The Necklace (XI):

Za mene ipak nešto fali 
u ovoj uzi bez raspeća,

na dragoj usni osmijeh mali

u čaši vode kita cvijeća.

Here is our translation, though not an entirely literal one:

And yet, there's something still I miss

from this crib without a cross,

a smile upon dear lips, the kiss

of flowers in a waterglass.

And here for comparison are two quatrains from In Memoriam (from sections $L$ and $C X X$ )

Be near me when the sensuous frame

Is rack'd with pangs that conquer trust

And Time, a maniac scattering dust.

And life, a Fury slinging flame [...]

I trust I have not wasted breath

I think we are not wholly brain,

Magnetic mockeries; not in vain,

Like Paul with beasts, I fought with Death [...]

And to oscillate further between the two poets, now compare the quatrains above with the following, also taken from The Necklace (XI):

Blaženo jutro koje padaš

u svijetlom slapu u tu sobu,

već nema smrti da mi zadaš,

no vrati ljubav ovom Jobu. 
Blessed morning, while you dress

this room in your translucent robe,

I've no fear of death's caress.

Only give love back to this Job.

As these examples suggest, from distant edges of Europe and across more than seventy years, Tennyson and Ujević present surprisingly strong similarities. We can't help noting the Biblical references in their punch-lines, while also knowing that neither poet was a believer. We also note their similarities in melancholic theme and tone, the oscillation between yearning, self-pity, regret, suppressed anger, and bitterness. And technically, we note that both poets deploy the tetrameter. Tin's patterns of versification derive directly from the rich tradition of South Slav oral poetry. In Tennyson's rhythms, as in those of many other English poets at least until the end of the 19th century, the sounds and echoes of the English and Scottish ballads are never far away. Tennyson's musicality has often been commented on, most famously by T. S. Eliot. In his ambivalent, contradictory essay on In Memoriam, Eliot writes: "He had the finest ear of any English poet since Milton" (Eliot 328) - even though, as Frank Kermode has pointed out, this is something of a backhanded compliment, because Eliot didn't much like Milton. ${ }^{[8]}$ (Was Eliot thinking of Lycidas? Might George Herbert's The Temple have been equally pertinent as a point of reference, with regard to overall structure as well as metrics and musicality?) However, Eliot's point is amplified, more interestingly, as he approaches his conclusion:

In ending we must go back to the beginning and remember that In Memoriam would not be a great poem, or Tennyson a great poet, without the technical accomplishment. Tennyson is the great master of metric as well as of melancholia; I do not think any poet in English has ever had a finer ear for vowel sound, as well as a subtler feeling for some moods of anguish. (Eliot 337)

If we replace "English" by "Croatian" here, and add "consonant sounds" to "vowel sounds" to include the dense clusters that give strength and body to the Croatian language, we actually discover an insightful perspective into Tin too, even if it needs to be acknowledged that Kolajna is a small collection of poems gathered loosely around a theme, rather than possessing the vaster, 
overarching structure of a self-cohering elegy such as In Memoriam: "a long poem made by putting together lyrics" (ibid. 333). Tin is indeed also a "master of melancholia" and the register and connotations of Eliot's terms - "subtler", "feeling", "moods" and "anguish" - combine to fit Tin as aptly, indeed perfectly, as they do Tennyson. As an expression of a certain "mood of anguish", 'Svakidašnja jadikovka' ('Daily Lament') is in a league entirely of its own.

At any rate, as I put these thoughts down, only now do I realise the extent to which the Tennysonian cadence must have underpinned the English versions that Daša Marić and I made more than twenty years ago. Even though it must be recognised that Ujević's expression is 'airier', 'lighter', and more modernistic than Tennyson's, at some subliminal level of awareness, I now see that I must have registered the many similarities between the two poets, not just in pace and rhythm, but in tone, mood, attitude and content. What is more, the issue of how to read (understand, configure) Tin's melancholia could scarcely be more aptly approached than by a comparison between these two. But I don't know if Tin ever read Tennyson. From his personal 'encyclopaedia', there's no evidence that he did.

While Tin's imagems seem to occur (appear) 'spontaneously', they can't avoid calling attention to themselves, not by any kind of forced forefronting but, as it were, just by 'being there'. These imagems are usually as direct and striking as is the interior feeling that they are associated with or embody. This is to say that, at their most effective, thanks to the quality of their artifice, they possess an ease and poise that is almost Zen-like; for so adroitly embedded is the craftsmanship in Tin's poems that craft itself appears to have become second nature to him, and what comes across is not 'craft' perceived as high gloss or superficial sheen but the impression of transparency, and hence the appearance of naturalness and simplicity. We have already mentioned "u čaši vode kita cvijeća" (translated as "flowers in a waterglass") as an imagem typical of Tin, accurate in its aptness and freshness. A similar plant-container appears in 'Star on High', where the observed scene fits the associated feeling so aptly that each might be said to 'define' the other:

ja sanjam još o cvijetu i sonetu, i o pitaru povrh trošne grede, 
flowers and sonnets occupy my dreams,

with plant-pots perched on seasoned wooden beams -

The visual picture is specific, precise, fresh and immediately visualized, in both languages. Furthermore, even if one doesn't know Croatian, one can scarcely fail to register the pithy sonic effect of the combined plosives and four rolled ' $r$ 's, in the line "i o pitaru povrh trošne grede", especially from the vocalic/r/ in "povrh". And here, incidentally, our translation has managed to carry over the alliteration on the /p/ ("pitaru povrh"; "plant-pots perched").

This kind of combined aural and eidetic effect illustrates a further crucial point about Tin's language: that the imagem coheres as a nexus of possibilities, all of which it unleashes simultaneously. It functions neither just visually nor just acoustically, but actively engages all speech organs: lips, tongue, hard and soft palate, larynx. Can one almost smell the flowers too? The effect of a line like this, then, is composed of all these sense impressions at once. And this observation leads in turn to the crux of the matter: richly textured and tissued in contrived artifice, Tin's imagems, while appearing 'simple' and 'transparent', operate synaesthetically.

As implied above, Tin's composite verbal patternings are inadequately described as literary 'devices' or 'techniques'. In this respect, they do not subsist just as images, which is to say, they do not function 'at a mere subsistence level'. Rather they are verbal embodiments of ways of actually experiencing and perceiving the world. To clarify this point further, at this point it is appropriate to delineate the term imagem in more detail.

When one is approaching a line like "i o pitaru povrh trošne grede", especially from the world-view of a speaker of English, the difficulty is that, if one is to do it the justice it deserves, the word image has become unsatisfactory as a descriptive or analytic tool. I suggest at least two reasons for this inadequacy. First, the word image privileges the visual faculty, and in so doing makes (and gives) inadequate 'sense' of the corresponding and equal primacy of all the other human senses: not only the aural and oral, but also the tactile and the olfactory, not to mention the as-yet-under-developed perceptual faculties that conventional registration of 'the five senses' in western discourse effectively serves to muffle, mask and minimise. Second, through generations of use by teachers 
and students in literature faculties, the word image has grown listless, vapid, effete. If it has not entirely lost its meaningfulness, whatever meaning does remain to it has become impoverished. Therefore, drawing more fully from the working definition outlined in the term's first appearance above ('a bundle or nexus of integrated or correlated images') ${ }^{[9]}$ I now deploy the word imagem to differentiate the kind of immediately apprehensible, composite and synaesthetic nexus that occurs frequently in Tin's poems, from the predominantly visual (eidetic) word image. Hence, by the word imagem, which is also a key to my own poetics, I intend a more comprehensive meaning, as follows: 'a fundamental cohering theme or motif present in and moving through a mental image' and therefore, in poetry, 'a cohering unit of interior consciousness expressed in a word or group of words, relating to the verbalisation of any sense impression or cluster (bundle, knot, group, combination, etc.) of sense impressions'. Founded (grounded, funded, routed, rooted) in and through synaesthesia, the imagem includes the eidetic but neither depends on it nor is limited to it. It necessarily embeds (compacts, engenders and releases) energy: a mood, a tone, a feeling ${ }^{[10]}$

As suggested in the previous example, some of Tin's imagems are very far from being imbued with anything like a merely vapid or effete elegance. Even in exploring 'decadence' itself, they are capable of unleashing a packed, almost explosive power. Consider these lines from The Necklace $(\mathrm{XX})$ :

U ovom mraku mirisavu

slušajmo kako ječe živci;

i sjećaju na ljutu travu,

a našem grču jesu krivci.

Listen how in this perfumed dark

our nerves' thin wires are twanged to flame

as if struck by a nettle's spark.

For wounding us, they'll take the blame. 
This imagem's composite artifice is immediately registered. We unpack co-occurring sensations: of smell (“mirisavu”, "perfumed”); sight (“mraku”, "dark”); hearing (“slušajmo", "listen”) and touch, from the suggestion of stinging ("ljutu travu”, "nettle's spark"). By their proximate juxtaposition, all these separate sense-words gather with focal precision into a pinpointing of inner sensation ("živci", "nerves"), almost as though an acupuncturist's needle had unerringly located and activated the qi ( chi, 'vital energy') on a series of points along and among the meridians of the 'listener'.

I'm aware, incidentally, that by bringing out these synaesthetic effects even more strongly than in the original (e.g. "our nerves' thin wires are twanged to flame"), the English version might well be charged with breaking the modest bonds (bounds, double-binds) usually imposed (or self-imposed) on a translator. My reply would be that in this breaking, I believe that the English remains loyal to the polysemic, multilayered imagem gathered in the Croatian, and even lifts it.

Yet even if what this poem is actually 'about' is clearly 'triggered' by the set of sense-responses indicated above, the range of topics in a poem by Tin, as well as the mind's movement through them, is considerably more complex. Approaching this imagem tangentially, I would add this: my personal response to the lines quoted above (which of course involves their transference or transformation into the English version into which Daša Marić and I have turned them) consists of the accurately recalled revitalisation of a bundle of experiences that are specifically Mediterranean. Though this poem's moment is by no means one of 'anguish', at least in this opening stanza, but rather one of plenitude, once again a 'subtle feeling' or 'mood' adheres to the entire imagem, as if it were a kind of sheen or haze around it, belonging to it, and in no way separable or extractable from it. For me, the poem re-evokes the rich, sweet, sad, ephemeral fullness (tristesse, tristezza, brama, čeznja, spokoj, etc.) of Mediterranean late afternoons and early evenings: that quiet time of the changing of the light, of ?? ???????, the approach of sumrak, dusk, when perfumes of flowers (jasmine?) and herbs (basil? oregano? thyme?) assault the senses, and the hum of cicadas swells against the background thrum of the sea's waves. These, then, are some of the constituents of the imagem which resonates at and through all layerings of my response. And as all these words leap out at me, they do so at once and together - Italian, Greek, Serbian, Croatian, French, English - 
brimming, spilling over, a cornucopia. This, then, models the kind of abbondanza (richesse) that I think Tin's finest poems gather and hold. And what is more, the containing of so much 'material' in poems that are so small and delicately carved seems all the more extraordinary. It is a miniaturised version of a Keatsian quality, and it has much to do with music! ${ }^{[11]}$

A further associative note: the composite quality of the imagem in this particular poem, the woof and warp of its particular tessitura, is perhaps most closely approached by the strikingly precise and evocative - and wonderfully long - German compound-word Sonnenuntergangs-traurigkeit: literally, 'sun-undergoing-sadness', i.e. 'sunset melancholy'. If you combine the sense of that with the Greek expression ? ????? ß?????ß?? [o ilios vasilevei]: i.e. 'the sun is kinging', roughly explicable as 'the sun is in his kingship', i.e. 'the sun is setting', and if you then throw in the English word longing - I think you may begin to get somewhere close to the overall feeling engendered in Tin's lines.

Furthermore, while this recall is at once ineluctably and vigorously sensual (physical, embodied, palpable, tactile, tangible, etc. - and sexual), it's necessarily indefinable as an experience. It can't be pinned down, because doing that would kill it, and it simply won't be killed. It refutes and refuses death, and, that refutation and that refusal of death constitute its ineradicable and irreducible affirmative core. For the imagem itself insists on leaping and diving about, connecting and reconnecting with and into far too many perceptual and experiential zones ever for it to be able to stay still for long enough to be (drearily) 'defined'. So the multidirectional way in which the experience moves, and tumbles back on and into itself, and the only way it can even (ever) be annotated verbally, has to be by synaesthetic hints, suggestions, stimuli, associations.

The principle of synaesthesia, of course, is one of the main keys that unlocks the myriad associative patternings which motivate and move both dream (san, songe, sogno) and memory ( sjećanje, memoria, $\mu$ ?? $\mu$ ?). It is no accident that by harnessing synaesthetic principles the philosophers and proto-scientists of the Italian Renaissance developed their art of memory ${ }^{[12]} \mathrm{A}$ poet such as Tin Ujević is perhaps to be regarded as one of their heirs. 
This irrepressible, vital quality in Tin's finest poems (among which I personally count Kolajna XX) is what I take to be one of his core qualities, because it opens up what I would describe as a huge 'vault' of perceptual potential in the reader. Here, I should like to explore this idea a little further, by means of a brief side-glance at William Blake. In The Marriage of Heaven and Hell (1793), Blake introduces the startling phrase "the abyss of the five senses". He continues:

How do you know but ev'ry Bird that cuts the airy way,

Is an immense world of delight, clos'd by your senses five?

(Blake, 'A Memorable Fancy' 183)

To Blake, closure within "the five senses" involves 'abysmal' limitation (and self-limitation), which prohibits the possibility of experiencing "delight". Imprisonment in the depths of (presumably Plato's) cave is contrasted with the aerial freedom of any flying bird. Furthermore, the precise wording here ("an immense world of delight, clos'd by your senses five") could be taken to imply that synaesthetic connectivity opens up far more than the sum of its component "five senses". As we know from evolutionary biology, when a richer and more intricate connectivity occurs among the parts of an organism, qualitative changes follow.

The image, I suggest, is a ratiocination that belongs to the Blakean abyss. Founded in a naive mimetic theory, it limits and suffocates. But the more intricate imagem, as deployed by Tin, not only opens and reveals abundance and vitality, but the "implicate order" and harmony within abundance ${ }^{[13]}$ Hence, Tin's finest poems entirely fulfil the demands inherent in my contention that a poet's role is to open up all the senses, not represent limited perspectives on 'reality' according to narrowly preformulated models of mimesis.

Yet, even after all this, there is still more to this particular poem, because it turns out that its theme is not just to do with the rush of feelings and associations conjured up at and by a certain place at and by a certain time, and reopened. For one's passage through the text's inner paysage also opens outwards into a historical attentiveness: as already suggested, to that point at which a 
civilisation, past its zenith, tumbles into decadence. The time is late afternoon, early evening; and the evening is (and is at and defines) the end of an era: 
U ovom muku punom boga

zalazi rujna epopeja;

nutrašnja kavga i nesloga

otkriva zelen niz aleja.

Umire naša lijepa tuga,

tuga od svile i barš una;

varava kao rosna duga,

zlatna i plava kao Luna.

In this deep hush, with glory filled,

our epic dawn sets, lost from view,

yet vision from this strife is spilled

through the green ranks of the avenue.

The beauty of our grieving frays,

its splendid silk and velvet folds

like dewy rainbows, fade in haze

fringed like the moon in blues and golds.

There is no 'l' in these lines: only an "our" / ("naša"), attached to the feminine noun phrase "lijepa tuga"('beautiful grief', 'lovely sorrow'), a stylised and sophisticated oxymoron, translated here as "the beauty of our grieving". (Aren't all oxymorons stylised and sophisticated?) Scarcely noticing this assumption of complicity, perhaps not even registering it other than subliminally, the reader is drawn into a sadness in which, collectively, 'we' somehow find 'ourselves' resigned, and yet proud and calm for all that. This is an 'attained', 'dignified', even ironic response - all of which adjectives 
need highlighting between quotation marks except (ironically?) the last one: because it is the key to the rest. And if I say 'ironic' - a term that may seem wholly unexpected and even misplaced in its attribution to Tin - I mean to imply an irony so subtle and sublime that it, too, is scarcely registered. Such a sophisticated and elegant feeling-response necessarily presumes a great deal of prior training and practice. It assumes civility, civilisation: the polis and its shared history. Cunningly, unobtrusively, delicately, this imagem reconstitutes the components of the fin-de-siecle into a specific moment, and leaves it there, poised. 
As for the formalities of technique in Tin's lyrics, the mot juste is always aptly placed; the rhythm is an accurate and correct embodiment of the content; and even though rhyming is easy to achieve, perhaps even too easy, in a language as highly inflected as Croatian, Tin's rhyme-choices are nearly always interesting, often brilliant, rarely merely facile, and never banal. Consider for example the untranslatable pleasure in the chime between epopeja and aleja in lines 2 and 4 of the poem just quoted.

In the felicitous cohering of all such elements in Tin's most effective poems, form achieves a kind of pearly or jewelled perfection. It appears effortlessly; so much so that, for all his individuality, and for all its pressure, the voice of the individual ' $l$ ' in these poems seems to rise out of the language itself, and therefore to be interpretable as celebration of the language itself: of what is inherent and inherited in it.

I hope the examples already given, at least in Croatian, adequately illustrate this quality. But for an Anglophone reader this last suggestion may need more clarification. What I mean is that the specific character and qualities of the Croatian language are opened up, all at once in Tin's lines: its compression, its accuracy, its range; its ability to express, precisely and immediately, visual and sonic detail, and sonority, depth and range of feeling. If a language, any language, can be said to possess anything like a genius of its own, then Tin embodies a particular expression of the genius of Croatian that stands and will stand, monumentally. This is one of the keys to his masterly art: the synaesthetic impression of naturalness.

Both the pearly, opaque quality and the associated sparkling and 'jewelled' quality are things Tin himself was aware of, as is evident in the title he chose for his 1926 collection. This multifaceted and recurrent imagem calls for detailed focus and exploration. It is obvious that the title Kolajna ( The Necklace) designates the book itself, with the concomitant indication that the individual poems in it are the necklace's pearls and precious gems and metals. Each poem is indeed a small, worked object, crafted to be beautiful, valued and treasured. No less obviously, throughout the sequence the predominant idea is also implicit that the maker and giver of the necklace which is 
studded with all these precious things is the masculine persona of the poet himself, while the implicitly feminised 'you' who is the recipient and 'addressee' of the necklace is the reader.

Tin introduces several variations on this theme. In traditional Croatian village costumes, women used to adorn their clothes with ornately embroidered pinafores or waistcoats and with necklaces made of coins and jewellery: their dowries. The dowry itself was worn on the breast and around the neck. Consider the two final verses of The Necklace (V):

Nisam li pjesnik, ja sam barem patnik

i katkad su mi drage moje rane Jer svaki jecaj postati će zlatnik, a moje suze dati će đerdane.

- No one samo imati će cijenu, ako in jednom, u perli i zlatu kolajnu vidim slavno obješenu ljubljeno dijete, baš o tvome vratu Though I'm no poet, I do know pain so I must love my human hurt.

So, from my tears, I'll braid a chain to ornament a dowry shirt.

- With pearl and coins of minted gold worth more than any poet wrote if only, my beloved child, you'll wear my necklace at your throat. 
The keyword here is the culturally specific, untranslatable, perfectly placed "đerdane" in the fourth line; and we can scarcely fail to register or underestimate the quality and authenticity it brings to the rest of the poem, even through the over-determined and inadequate English explication, "dowry shirt" (inadequate because over-determined).

'Đerdan' (in the nominative) is a specific and localised term that derives from the Turkish word gerdan, meaning 'neck, throat, front of the neck, with the compound gerdanlik, 'necklace' (Hony 119). Tomislav Kuzmanović clarifies this etymology, as well as the term's meaning, register and usage:

'Đerdan' is a dowry necklace, usually of gold coins. This isn't a word used in everyday speech, so I wouldn't say it's exactly 'standard' Croatian. Nor could I say, though, that it belongs to only one dialect (that of Slavonia). I'd be more inclined to view it as an expression of tradition, meaning 'a specific kind of necklace'. Here again, the word is not one that would be used in any context other than in specific relationship to a folk costume: more precisely, the most precious (and prized) part of the costume worn at weddings - which is probably meant to imply the happiest moment in one's life'. So, in this respect, the word carries connotations of something extraordinary, precious, extremely valuable, etc. ${ }^{[14]}$

Clearly, translation of the word "đerdane" cannot avoid being inadequate (cannot fail to fail), simply because the dowry custom is by and large obsolete in English-speaking countries. Yet by this word's delicate, detailed, aptly-placed and perfectly pitched specificity in Croatian, the entire composite imagem of the folk-wedding that develops in the final stanza is grounded, potentialised, informed: "u perli i zlatu", "kolajnu", "tvome vratu"; "pearls and gold", necklace", "your throat". Kuzmanović's comment enables the entire marriage custom to come alive, illuminating how this dense, complex detail (a word-gem in itself) is the key that unlocks the fuller perspectives of the poem in its cultural context, which would otherwise have been all too easily lost in translation. For the necklace is neither merely ornamental nor merely a displayed or displaced 'symbol' of the dowry. Rather, the necklace, whose function and meaning imply and carry the irreducible imagems of 'display' and 'bodily adornment', is and constitutes the dowry itself. 
Furthermore, since it is traditionally the family of the bride that provides a dowry, and since the speaker's addressee ("you") is "ljubljeno dijete" (a "beloved child"), the reader is perhaps entitled to assume that the persona in the poem is a father addressing his daughter. If this reading is indeed implicit, the speaking 'l' will then fit the voice of any father, that is, any 'typical' family man who upholds the tradition of country-folk by 'giving his daughter away' in marriage. Such a reading reintegrates and makes full sense of the first line, which otherwise would have been lost. So the jaunty, highly idiomatic statement "Nisam li pjesnik, ja sam barem patnik" (translated as "I'm no poet, but I do know pain") is one that can be made by any 'ordinary' man, who despite stereotypical masculine inarticulacy in the sphere of feelings, here endeavours to express the whole complexity of interconnected feelings and thoughts that suddenly flood through him, as he stands beside his daughter at the altar.

What is more, since the first line quoted here (actually belonging to the second stanza of the poem) is clarified by the last stanza, the poem demands to be read several times. Its moment, then, can be read safely as a poignant and delicate one, which allows a traditional 'masculine' male to open up and express and ponder over his tenderer feelings, and to do so without embarrassment - even if he isn't "a poet". The issue of embarrassment, then, is one that is consciously focused on, and addressed here, with full decorum. This reading of the poem attains a psychological accuracy which otherwise it would not possess.

The finest comparison from the English tradition to the situation so subtly and - it must be emphasised - tactfully embedded in this poem is to be found, I believe, in a passage by Tin's contemporary, D. H. Lawrence, in Chapter 5 of The Rainbow, entitled 'Wedding at the Marsh'. Here, the narration registers Tom Brangwen's thoughts and feelings as his attention drifts to the stained glass window of the church in which he is giving away his daughter Anna, as he too stands beside her at the altar. Here is the abbreviated gist of the passage, with some phrases highlighted. The italicised phrases are recognizably applicable to Tin, both to the this poem and to others:

Brangwen was staring away at the burning blue window at the back of the altar, and wondering vaguely, with pain, if he ever should get old, if he ever should feel arrived and established. With a pang of anguish he realised what uncertainties they both were. [...] How did one grow old - how could one become confident? He wished he felt older. [...] He felt himself tiny, a little, upright figure 
on a plain circled round with the immense, roaring sky: he and his wife, two little, upright figures walking across this plain, whilst the heavens shimmered and roared about them. When did one come to an end? In which direction was it finished? There was no end, no finish, only this roaring vast space. Did one never get old, never die? That was the clue. He exulted strangely, with torture. He would go on with his wife, he and she like two children camping in the plains. What was sure but the endless sky? But that was so sure, so boundless.

Still the royal blue colour burned and blazed and sported itself in the web of darkness before him, unwearyingly rich and splendid. How rich and splendid his own life was, red and burning and blazing and sporting itself in the dark meshes of his body: and his wife, how she glowed and burned dark within her meshes! Always it was so unfinished and unformed!

\section{(Lawrence 134-35)}

$* * *$

According to the above interpretation of Kolajna $(\mathrm{V})$, the poem is a dramatic monologue, a speech made by a character in an implied fictional situation. Evidently, such an interpretation is dependent on the assumption of a high degree of conscious craft on the part of the poet and a complicit recognition and speed and elegance of response from the reader. For this interpretative facet sits neatly side by side, and without contradiction or conflict, with the macro-imagem of the necklace itself, which applies to the whole collection: every poem in it being 'strung' on the 'necklace' that is itself the book. But when it comes to Kolajna $(\mathrm{V})$, the necklace imagem functions as a microimagem too: for Kolajna and "đerdan" are one, or rather each is a version of the other. That is to say, this particular poem is at once a precious coin or pearl strung on the chain of the book and an entire dowry-necklace in its own right. In this way there is a kind of fractal replay (interplay) of the imagem, at both macro and micro levels. The refractions branch multi-directionally and become more and more complex. As I have suggested before, this is the art of filigree.

By the same token, in this poem too, the reader is feminised as the poet's imaginary daughter, the recipient of the "đerdan" (dowry necklace), i.e. the poem itself. And if this is so, and the "I" in the poem is readable as a conflation of two personae simultaneously - first the poet, and second 'any' father addressing his daughter whom he is 'giving away' as bride - then the conceit could also 
ramify, playfully, into the "you" in the poem being interpretable as the poet's daughter, and the recipient her bridegroom, who is the receiver of the gift her father 'made' and is now 'giving away'.

[15] Structurally, therefore, the concurrent (polysemic, multifaceted) interpretations of the poem that are possible can be represented by means of a table, in which each item within every column may replace and stand for any another:

Giver / maker makesgift and gives it to recipient

Jeweller (minter?) makes necklace (filigree) and gives it to woman

Worker earns ('saves') coins (money) and gives them (it) to family

Father / parent makes ('creates') daughter and 'gives' her to bridegroom

Poet / authormakes book of poemsand gives it to reader

Poet / authormakes poem and gives it to reader

According to this reading, the 'lie' of the first line, "I'm no poet" - a lie because we know perfectly well that Tin is a poet, and an accomplished one - inevitably becomes a rhetorical conceit, and, what is more, one through which we are bound, inescapably, into artifice. Here, I can't help being reminded of the 17th century English courtier poets Herrick and Lovelace. The poem is readable, then, as an intricate, delicate word-game: at once punning, light, playful, sweet, sad, self-aware, urbane, and self-ironic. Urbane and self-ironic above all. As for the vexed questions of 'sincerity' and 'authenticity', they dissolve into irrelevance: any notion that the poem is a self-pitying and cloying personal confession disappears.

And yet... And yet, such a reading, plausible and appealing though it may be, does not really 'solve' the issues of authenticity and sincerity that crop up in readings of many of Tin's poems. While the finest of them (among which I do not myself count this one, despite its evident qualities) are investigations of melancholia, some of the weaker poems do rely so much on a sweet, 
superficial facility that they fail to achieve emotional complexity. The sentimental chord is undeniably present just beneath the surface of this poem too.

So for this particular poem, a contrary reading, admittedly a rather naive one, might proceed along the following lines. We know that the opening statement, "Nisam li pjesnik" ("I'm no poet") is a lie, just as the idea of Tin having a child is also (so far as we know) biographically untrue. He lived and died a bachelor. So any impression of 'sincerity' that the second stanza is supposed to give is not merely contradicted, but vitiated from the start. According to this reading, then, the entire feeling of the poem is inauthentic, weakly sentimental rather than genuinely felt: specious, the epitome of in sincerity.

Furthermore, if this kind of interpretation occurs specifically in translation, the reader might then reach one of several conclusions: for example, that the original poem is too plangent to 'cross over' into English; that the melancholy in Croatian veers towards a rhetorical self-pity, which somehow does not 'fit' or seem 'right' in English, with the result that in English, even if not in Croatian, the blurry line between a pressured containment ('decorum', 'taste') and embarrassment has been breached. An alternative variant of such a reading might be that the English translation itself, rather than the original Croatian, is the vessel that leaks plangency, whether because this particular translation contains too many hair-cracks and is simply not 'firm' enough (not 'good' enough, not 'loyal' enough) to hold the original, or because the 'core' or 'essence' of the 'original' is so culturespecific that it is inherently untranslatable. Either way, the entire poem will arouse in the reader something between a mild irritation and the sour taste of having being cheated. According to such a reading, then the necklace cannot be made of gold and pearl: it is an imitation, a fake.

When all is said and done, I think a reading that goes to these lengths of disapproval has to be a misinterpretation, because by failing to register the implications of the word "đerdan", it does not take into account the notion of dramatic monologue explored above, insisting rather on the assumption that the poem's entire function is a naive kind of self-expression: a naive assumption in itself. That is to say, such an interpretation involves the reader's projection of the vice of naivety onto the poet, a charge which should rightfully be directed back to the reader. So too should similar charges of 'insincerity', 'lapse in taste', etc. Such a reading, it could be argued, posits a failure to 
respond to the precise quality that makes any poem a poem: its foundation in an art, a craft, in Italian a mestiere.

Again, and yet again... it has to be said that it is hard not to trace a tinge of at least some such 'decadence' at some level of response to this poem. This issue recurs in readings of too many of Tin's lyrics to be entirely dismissible: there is an ambivalence, and I believe it is one that is necessary and inevitable... Perhaps the frisson discharged by this kind of ambivalence belongs to all 'decadent' art, as one of its defining features... Anyway, I bring in the words "necessary" and "inevitable", because the element of embarrassment or irritation in the reader's response, whether dominant or subliminal, is part of the risk that Tin knowingly takes in exploring feeling. He sometimes tumbles into sentimentality, sometimes wobbles and teeters on its edge, and sometimes precariously balances over it without falling and, so, steadily and successfully confounds it. Finally, "exploring feeling" in turn opens up a wider and more significant issue: Tin's constant willingness to remain open to 'beauty', despite the infinitely repeated paradox of its occurrence in or alongside pain and death.

I take my next cue from the suave and melancholy oxymoron "lijepa tuga" ('beautiful grief' or 'lovely sorrow', which in our translation becomes a line that I'm entirely happy with, "the beauty of our grieving frays") in line 4 of the above poem. And here I turn to the wider question of 'beauty', and its associations with death and pain in Romantic and post-Romantic poetry. This turn (ß????, volta ) necessarily moves onto a digressive path away from Tin himself, but it is one which will lead back to his poems, hopefully opening a deeper, richer seam into and through them.

In English, the pinnacle of the tradition that associates and sometimes identifies beauty, pain and death is of course to be found in Keats. Incidentally, there is no evidence, so far as I know, that Tin had read Keats, any more than he had Tennyson or Eliot. Yet Tin's phrase, just pinpointed, can hardly fail to remind an English reader of the masterly 'Ode to Melancholy', of lines like "drown the wakeful anguish of the soul", and the magnificent and unforgettable last stanza:

She dwells with Beauty - Beauty that must die;

And Joy, whose hand is ever at his lips 
Bidding adieu; and aching Pleasure nigh,

Turning to poison while the bee-mouth sips:

Ay, in the very temple of Delight

Veil'd Melancholy has her sovran shrine,

Though seen of none save him whose strenuous tongue

Can burst Joy's grape against his palate fine;

His soul shalt taste the sadness of her might,

And be among her cloudy trophies hung.

Other relevant poems by Keats are the 'Ode on a Grecian Urn', with its line "Beauty is truth, truth beauty”, and his eerie 'La Belle Dame Sans Merci' The tradition eminently carves a broad avenue through French, sweeping in measured magnificence out of the alexandrines of Racine and Corneille. For a paradigmatic piece, see for example Baudelaire's early poem 'Beauté', in which Beauty herself speaks to humans: "Je suis belle, ô mortels, comme un reve de pierre" ("I am beautiful, O mortals, as a dream in stone") (Baudelaire 26-27). The tradition then weaves through pretty well every European language and into a host of other 19th century writers, including Walter Pater. And here I draw on Angela Leighton's book, On Form, for its sweep of relevant commentary and its insightful and attentive interpretations:

Like his contemporaries, Pater loves the way that 'form' is itself a conditional word that can touch on abstractions, like 'beauty', as well as on beloved bodies. [...] 'Every moment some form grows perfect in hand or face', he writes. For Pater, [...] 'form' easily interchanges artistic and physical beauty. (Leighton 81)

This too is relevant to Tin. A few pages later, exploring Virginia Woolf, Leighton adds:

Pater's 'gemlike flame' goes on flickering in Woolf's work, appearing here and there in her prose like a sign of her controlling aestheticist yearning. 'Look! What a beauty!' cries Eleanor in The Years. 'A flame danced on top of the coal, a nimble and irrelevant flame.' Beauty, the 'irrelevant flame' can still get a 'nimble' footing on the coals in the twentieth century. (ibid. 96-97) ${ }^{16]}$ 
This is a brilliant and delicate observation, which will flood its slight, intense beam back on Tin's lyrical poems, illuminating them too. Leighton reminds us that the thread of 'beauty' does run, even though inconstantly and fitfully, through 20th century English poetry and fiction. To which I think it needs to be added: it runs not only throughout and out of the 19th century, somehow or other surviving into and through the 20th too, but out of it into the 21st. In 20th century literature, however, it is not a constant flame. Actually, it is irrelevant. It is non-functional. It is also irreverent. It doesn't fit. And for these reasons, it is awkward. It is discomfiting too, because it makes us feel awkward. But it is tough. Against the odds, it makes a come-back. It survives, even if only in patches and corners. In fits and starts. Fitfully.

Throughout the modernist and post-modernist period, 'beauty' has posed a huge aesthetic problem which refuses to go away. The core of this is already fully present and familiar in the 19th century, in Keats and in Baudelaire, where it resides in the detached, aloof indifference and, hence, amorality of beauty. This view is articulated precisely in Rilke, still writing within the aestheticist convention:

\section{Denn das Schöne ist nichts}

als der Schrecklichen Anfang, den wir noch grade ertragen

und wir bewundern es so, weil es gelassen verschmäht, uns zu zerstören

For Beauty's nothing

But beginning of Terror we're still just able to bear,

And why we adore it so is because it serenely 
Disdains to destroy us.

(Rilke 24-25)

In 'Easter 1916', Yeats's writes: "All changed, changed utterly: / A terrible beauty is born” (Yeats 203). But, as if the First World War were not enough to bury beauty once and for all in the trenches of Normandy, beauty's absolute nadir arrives for the whole world with the Nazi Holocaust, Stalin's purges and death camps, and the mushroom clouds over Hiroshima and Nagasaki. By the end of the Second World War, the amorality of beauty and the horror and pain it arouses is so acutely and directly juxtaposed against adjacent atrocity, that it becomes, literally, unbearable. It is so unbearable to Adorno, that at one point in his intellectual career he even recommends that there should be no more lyric poetry after Auschwitz (Adorno 19). Yet of all the poems in the world, in a poem that is still a lyric and still incapable of ending in a full stop, this juxtaposition is pitched most ironically, most bitterly, most excruciatingly, most unforgettably - incomparably and for all time - in Paul Celan's 'Todesfuge' ('Death Fugue'), published in 1952. It ends with its 'lyrical' refrain to end all refrains:

\section{Der Tod ist ein Meister aus Deutschland}

dein goldenes haar Margarate

dein aschenes Haar Sulamith

Death is a master from Germany

your golden hair Margarete

your ashen hair Shulamith

(Celan 52-53) 
We note: there is no shrinking from beauty here. Nor I believe is there any such shrinking in the entirety of Celan's work, all of which addresses this issue, and does so in and through pain. Next to this, however, the reaction of modern English poets against beauty seems pitifully inadequate and provincial. Philip Larkin's contribution, for example, whose writings for some inexplicable reason remain wholly acceptable to contemporary English taste, is to offer a piece of crude, crass, infantile burbling contra Keats: "Ah, beauty, beauty! What is truth? Balls. What is love? Shite. What is God. Bugger. Ah, but what is beauty. Boy, you got sump'n there. I should like to know" (Larkin 26, quoted in Leighton, op.cit: 39). It is curious, too, to remember that Larkin's first book, the North Ship (1945), was inspired by Yeats, one of the self-confessed "last Romantics"[17] Among poets writing in the English language since Yeats, there have been plenty of waves of fashion and taste including several predominant contemporary schools on both sides of the Atlantic - which refute, deny or altogether avoid beauty, dismissing or ignoring most if not all of the challenges thrown down by the poets quoted above, and doing so, inevitably, to the detriment in quality of the poems they engender and advocate. Tin's poems, however, are balanced on a high wire of emotional intensity, and although not all of them avoid the occasional wobble - even tumbling into sentimentality - some of them do walk the tightrope with unerring poise and sureness of footing. Tin in the 1920s takes on the whole of the European Romantic tradition.

As I have already noted, we do not know if Tin read Tennyson or Eliot. But we do know that he read Proust and the French Symbolists. And if he might have aspired to the mordant intensity of Baudelaire, the tone he actually attained more frequently turns out closer to the languid melancholy of Verlaine. Tin's most famous anthology piece is probably this perfect miniature (The Necklace $\mathrm{XXI):}$

Noćas se moje čelo žari, noćas se moje vjeđe pote; i moje misli san ozari, umrijet ću noćas od ljepote. 
Duša je strasna u dubini,

ona je zublja u dnu noći;

plačimo, plačimo u tišini,

umrimo, umrimo u samoći.

The apparently 'natural' and unforced musical quality of this highly wrought piece is beguiling, with its moody alliterations and vowel harmonies, its intent and monotonous mimetic repetitions of consonants, words, rhythms and syntax, all of which embody and ramify the weight and intensity of the melancholy. For reasons that, once again, I think are less to do with 'language' boundaries in the narrow sense than with variances in cultural attitudes, especially vis-a-vis embarrassment and sincerity (which, as we have seen, in turn embroil issues of decorum and taste), this particular poem may well be impossible to reproduce, or transmute, in modern English. Even so, I hope what follows is not too distant an approximation:

Tonight, my forehead gleams

and sweat drips in each eye;

my thoughts blaze through dreams,

tonight, of beauty I shall die.

The soul's core is passion deep

in night's abyss, a blazing cone.

Hush, weep in silence. Let us weep

and let us die. We'll die alone.

However hard I tried to get it right, this was one of those translations that refused ever to come out quite as I wanted, or rather, exactly as I felt I was 'hearing' it, at a kind of 'subverbal' even 'babbling' level, in my head.

Even so, everything about the achieved Croatian original reminds me of Verlaine: its melancholy, of course; but also its precision of timbre, its finesse of tone, its sonority balanced between tears and fire. It might even be suggested that, within Croatian tradition, this poem epitomises the fin-de- 
siécle 'moment' as perfectly as Verlaine's 'Art poétique' ("De la musique avant toute chose") and "II pleure dans mon coeur" do in French. More interestingly still, the line "umrijet ću noćas od ljepote", "tonight, of beauty I shall die", succeeds in calling up (or, as Stanley Cavell would put it, calling upon, calling out (Cavell 1979)) an entire tradition of 19th century European poetry, which associates 'beauty' with death. And what is even more striking in this eight-line poem is that more or less every other core-ingredient of that tradition manages, explicitly or implicitly, to be present too. Here, as stated motifs, we find fire, depths, passion, dreams, tears, and loneliness; and, as constant undertows through the poem's movement, form and music.

Tin's minuscule Croatian poem, a gem in his Necklace, gathers up this entire tradition of responsiveness to 'beauty'. Here, as elsewhere, Tin's writing draws directly on the French tradition rather than any English models. Unfortunately I am not well-versed enough in 19th and early 20thcentury Croatian and Serbian poetry preceding Tin to be competent to point to specific models in his own language. But actually, for the point I want to emphasise here, the issue of Tin's direct sources doesn't really matter, precisely because the tradition of 'beauty' is pan-European and pervasive, with variations through all its local expressions and examples. Patterns of influence move back and forth and intersect and intertwine. What is more interesting is that Tin's poem, like all the others in Kolajna, happens so very late in the story of 'beauty': its year of publication is 1926 - that is, after the Futurist Manifesto, after Imagism and Dadaism, after the First World War poets such as Guillaume Apollinaire, Albert Michel, Wilfred Owen, Isaac Rosenberg, Siegfried Sassoon, August Stramm, Georg Trakl, Ernst Toller and Giuseppe Ungaretti, and after the publication of The Waste Land. To say the poem is retrospective and nostalgic, then, seems like an understatement. The mood is appealing, charming, even seductive.

This anthology piece is immensely popular in South Slavic countries. It is Tin's anthology piece par excellence. At this point, however, I want, deliberately, to delineate a contrary response to this poem, one that does not 'fall for' its seductiveness, but rather, challenges it. In line with other comments made above, putting forward such a view, I hope, will not only address the ambivalence that Tin's work can call up in his readers, but also eventually spiral back into suggestions of a richer complexity - including a series of fault lines - in his writing, both of which may well be masked by the very fact of his popularity. 
According to such a response, this poem, this perfect miniature gem in The Necklace, teeters on the brink of sentimentality. For one thing, so intensely beautiful is the "beauty" ("ljepote") the speaker experiences that he will "die" of it. This statement is over-the-top, self-dramatised to the point of being histrionic; and not just over-the-top, but obviously so, even to the point of parody or, perhaps, self-parody. And could there even be a threatening undertone to the self-pity? From a sober, detached, mature (etc.) point-of-view, the voice seems akin to that of a breathy teenager's: self-indulgent, self-serious, gasping, impossible to take seriously, even in the very moment of appearing to need to be taken very seriously, a message that parents might heed, even if only for safety's sake. Here is the first layer of ambivalence.

What is more, the statement "umrijet ću noćas od ljepote ("tonight of beauty I shall die", line 4) provides the key to the entire poem. It unlocks the final statements in lines 7 and 8: "plačimo, plačimo u tišini, / umrimo, umrimo u samoći." A literal translation of these lines is: 'Let us weep, let us weep in silence, / let us die, let us die alone / in aloneness.' So the first person singular statement opens into the plural: the extreme condition that applies to the poet's confession about his own present (not only weeping but also dying of weeping) heralds the generalised statement that 'we' - actually or potentially or both - are in this condition too, and lonely to boot. The conclusion then is that 'we' mortals are all tortured by beautiful moments, that beauty turns us all into miserable, pathetic sufferers, that 'beauty kills us all.' It must be admitted here, too, that the twice repeated injunction "Let us" of our English translation, combined with the predictive "We'll die alone" does not quite gather the multiple complexities inherent in the deceptively simple, condensed Croatian.

Moreover, apart from the fact that this leap from singular to plural is a non sequitur, it is hard to conclude whether this movement from ' $\mathrm{l}$ ' to 'we' is profoundly poignant, or pathetically plangent. Here, then, is a second layer of ambivalence in a possible response. Could Tin even have written this tongue-in-cheek? And was this his supreme Hollywood moment?

Probably neither. But consider: the year when Shelley published his most over-the-top line, "I pant, I sink, I tremble, I expire”, was 1820. In its context in the long and rambling poem 'Epipsychidion', 
that line oozes an excruciatingly embarrassing sincerity. Keats's ‘Ode on a Grecian Urn’ was written in 1819 and published in 1820. One hundred and six years later, Tin's poem is an echo chamber in which all the bells of Romanticism continue to jangle, discomfitingly, awkwardly, irrelevantly.

Now for the opposite view, which is the one I actually hold. Within the broad zone of influences and conventions, my first counter-contention is that Tin's poem still, and against all the odds, manages to belong entirely 'to itself'. And I think it does so in quite complicated and subtle ways. Of these, I shall list six.

First, as in Kolajna (V), if the ' $\mathrm{l}$ ' in this poem is considered as a persona, and if therefore the poem is read as a dramatic monologue, and hence as a fiction, the whole functions as a statement of a certain mood that I believe most people over the age of sixteen have experienced and recognise.

Second, according to this line of thinking, from the point of view of psychological insight and empathy, the statement could not be more exactly delineated and portrayed.

Third, to expand and justify the first two points, the poem's artifice is not only perfect but tactfully and discreetly evident as undertone or, rather, as undertow to the waves of feeling that crash across its surface. Hence the first impression of an urbane, polished, plausible veneer is beguiling. The poem's 'deeper' effectiveness resides in its clever impression of physical immediacy. For example, the keyword "noćas" ('tonight') is repeated three times and further heightened by a further indication of night: "u dnu noći" ('the bottom of night', 'the depths of night', translated here as "night's abyss") The effect of these repetitions is to draw the reader back, again and again, into its poised moment. All this suggests that, even in terms that a critic as taxing as F. R. Leavis might have applied as a test of quality, the poem is in his terminology 'realised' (real-ised: made real).

Fourth, the poem's entire vocabulary-set resonates a sexual register, which, together with its repetitions and rhythms, combine to suggest a powerful erotic movement. This is traceable from the passionate and soulful isolation of the ' $\mathrm{l}$ ' in the first stanza, burning and sweating in tears, to the four-times repeated "-imo" verb-ending in the last two lines, indicating 'we': "plačimo, plačimo... / umrimo, umrimo", "we weep, we weep, / we die, we die". If the 'we' here is interpreted as two 
people together, rather than as a generalised indication of community and communality, the piece becomes readable as a love-poem of extraordinary delicacy and gentleness. While indications of jouissance, of le petit mort, once drawn attention to, could scarcely be more evident ("umrimo, umrimo"), this layer of meaning, though constantly present, is never overstated. The erotic layering is subtle and tactful. And its very last phrase, "u samoći" ("alone"), also provides the second half of an oxymoron, since grammatically the act or process of 'dying' here is something that involves 'us' both, together ("umrimo, umrimo", "we die, we die"); for, if 'we' "die" 'together', how can we be "alone"? Hence, this final "alone" is many things at once. At the first level, it is a return to isolation: after the intensity of "beautiful" passion, after its movement and its moment, to post-coital sadness, to the "lijepa tuga" ('beautiful grief' or 'lovely sorrow') already encountered in another poem. At the second level, it is a statement about mortality itself. As Derrida has clarified once and for all, it is literally impossible to 'die for another.' Dying by definition is and has to be done, inevitably, by every mortal being, by oneself, alone (Derrida 1995). And thirdly, the finest, purest and most poignant moment of Keatsian music is recalled here, that at which the nightingale abandons him, and he is left with his "sole self" (Keats 231):

Forlorn! the very word is like a bell

To toll me back from thee to my sole self!

Adieu! the fancy cannot cheat so well

As she is fam'd to do, deceiving elf.

Adieu! adieu! thy plaintive anthem fades

Past the near meadows, over the still stream,

Up the hill-side; and now 'tis buried deep

In the next valley-glades:

Was it a vision, or a waking dream?

Fled is that music: - Do I wake or sleep?

And fifth, quite apart from these kinds of comment, which are, after all, the familiar stuff of traditional literary criticism, a simpler point needs making out of them: this poem's immense 
popularity throughout former Yugoslavia itself suggests that, far from being merely shallow, selfindulgent, sentimental or specious, it touches a chord that is genuinely transpersonal, communal, resonant and deep.

My sixth and final argument, then, which incorporates all the previous ones, is that to interpret this poem as merely conventional can only be a misreading. While being no more or less than what it is, Tin's poem epitomises an entire convention, sums it up, and comments on it. Indeed I would make a further claim: that this is a great poem both for what it is and does, in itself, and also because it stands on a time-threshold, firmly, without faltering or collapsing. In doing so, it looks back across a huge panorama. This minuscule poem, written in Croatian, (not French, not English, not German, not Italian) is the entire summation of the 19th century tradition. I do not see how that tradition could be taken any further than this. The last Romantic is not W. B. Yeats but Tin Ujević. And to a reader reading these lines in any now you might care to specify - all readings happen ineluctably in a now - Tin's poem issues a challenge for the future. It says: I looked at beauty. Whatever fears and ambivalences you may have, you have beauty to deal with, too.

***

T. S. Eliot's essay on In Memoriam contains both unqualified praise and measured though snide qualifications. Taken together, these adumbrate Eliot's own complex and ambivalent response towards Tennyson: his debt, his genuine admiration, his 'emotional' response, as well as his unease as a modernist looking back into the previous century. The remarks already quoted above are quoted often enough. But then Eliot adds this:

The surface of Tennyson stirred about with his time; and he had nothing to which to hold fast except his unique and unerring feeling for the sounds of words. But in this he had something no one else had. Tennyson's surface, his technical accomplishment, is intimate with his depths: what we most quickly see about Tennyson is that which moves between the surface and the depths, that which is of slight importance. By looking innocently at the surface we are most likely to come to the depths, to the abyss of sorrow. (Eliot: 337)

Whether we agree or not with Eliot's ambivalent, combined denigration and adulation of Tennyson, here again I think we do find insights that are applicable to Tin's lyric poems and profoundly helpful 
in our attempts to 'understand' them. And just as Tennyson generates an ambivalent response in Eliot, so, I wonder if Tin may also generate an ambivalent response in readers. If so, it is hard to say, of course, whether such an ambivalence might be 'typical' of readers' responses. My guess is that this is not so, at least in his own language, especially since Tin's status in Croatia currently approaches that of 'national poet', to the extent that it might be compared with, say, that of Robert Burns in Scotland. It is also a moot point whether such an ambivalence, if consensual, might suggest an inherent flaw in his genius. That suggestion is left open here.

I conclude these notes with an all-too-brief brief glance at 'Svakidašnja jadikovka' ('Daily Lament'). The waves of emotion released in Tin's poems can often be so raw in delivery that their effect is stunning, sometimes leaping and tumbling, almost as it were vertically, through, across and out of the rippling horizontality of his formal rhythms, in a discomfiting, awkward, agonized cry. Here, the poem's voice assumes the power of an Old Testament Job berating God:

O Bože, žeže tvoja riječ

i tijesno joj je u grlu,

i željna je da zavapi.

Ta besjeda je lomača

i dužan sam je viknuti,

ili ću glavnjom planuti.

Pa nek sam krijes na brdima,

pa nek sam dah u plamenu,

kad nisam krik sa krovova!

O Bože, tek da dovrši

pečalno ovo lutanje

pod svodom koji ne čuje.

Oh God, you sear your burning word 
too hugely through this narrow throat

and throttle it inside my cry.

And utterance is a burning stake

though I must yell it out, I must,

or like a kindled log, burn out.

Just let me be a bonfire on

a hill, just one breath in the fire,

if not a scream hurled from the roofs.

Oh God, let it be over with,

this miserable wandering

under a vault as deaf as stone. 
Here is another poem that takes every imaginable risk. It is, in all senses, on the edge. But in terms of modulation, pace and emphasis, the patterning here is flawless. 'Svakidašnja jadikovka' ('Daily Lament') is Tin's lyrical masterpiece. Unrhymed, but with an inescapable, incessant, pounding rhythm, it insists, with slow inevitability, on successive waves of feeling that tumble over one another in rapid succession, oscillating between unease, anxiety, angst, anger, anguish and despair. I think this is a universally powerful poem. I don't believe there is a human being, however sanguine, who hasn't at some time felt something of what it expresses. Finally, what is most astounding about it is the vitality, vigour and dignity that pulse through it: its beat, its breath, is paradoxically most full of life even in the fullness of its diatribe against life.

Cambridge

June 13-20, 2011

Acknowledgements

For Daša Marić

My thanks to Paul Scott Derrick, Tomislav Kuzmanović and Clive Wilmer for their helpful comments on drafts of this essay.

\section{Books}


Adorno, Theodore. 'An Essay on Cultural Criticism and Society'. Prisms. Trans. Samuel and Shierry Weber. Cambridge, Mass.: MIT Press, 1967 [1949]. Print.

Baudelaire, Charles. Selected Poems. Ed. Francis Scarfe. Harmondsworth: Penguin Books, 1970 [1961]. Print.

Blake, William. The Poetry and Prose of William Blake. Ed. Geoffrey Keynes. London: The Nonesuch Library, 1956 [1927]. Print.

Bohm, David. Wholeness and the Implicate Order. London: Routledge, 1980. Print.

Cavell, Stanley. The Claim of Reason. Oxford: Oxford University Press, 1979. Print.

Celan, Paul. Poems. Trans. Mivhael Hamburger. Manchester: Carncaet, 1980. Print.

Chou, Eva Shan. Reconsidering Tu Fu, Literary Greatness and Cultural Context. Cambridge:

Cambridge University Press, 1995. Print.

Davie, Donald. Purity of Diction in English Verse. London:Chatto \& Windus, 1952. Print.

Derrida, Jacques. The Gift of Death. Chicago: University of Chicago Press, 1995 [1992]. Print.

Eliot. T. S. 'In Memoriam'. In Selected Essays, pp. 328-338. London: Faber \& Faber, 1961 [1936]. Print.

Hass, Robert. 'One Body: Some Notes on Form', in his Twentieth Cdntury Pleasures. New York: Harper Collins, 1984. Print.

---. The Apple Trees at Olema: New and Selected Poems. New York: Harper Collins, 2010. Print. Keats, John. Poetical Works. Ed. Harry Buxton Foreman. London: Reeves \& Turner, 1885. Print. Larkin, Philip. The North Ship. London: Faber and Faber, 1945 [1982]. Print.

---. Selected Letters: 1940-1985, ed. Anthony Thwaite. London: Faber and Faber, 1992. Print.

Lawrence, D. H. The Rainbow. London: Penguin Books, 1978 [1915]. Print.

Leighton, Angela. On Form: Poetry, Aestheticism, and the Legacy of a Word. Oxford: Oxford University Press, 2007. Print.

Oxford English Dictionary, the Compact Edition. London: Book Club Associates, 1979 [1971]. Print. 
Partridge, Monica. Serbo-Croat: Practical Grammar and Reader. 3rd ed. Belgrade: Prosveta, 1988. Print.

Ricks, Christopher. Keats and Embarrassment. Oxford: Oxford University Press, 1974. Print.

Rilke, Rainer Maria. Duino Elegies. Trans. J. B. Leishman and Stephen Spender. London: Hogarth Press, 1963 [1939]. Print.

Roethke, Theodore. Collected Poems. New York: Anchor Books, 1966. Print.

Shelley, Percy Bysshe. Epipsychidion, 1820. Print.

Tennyson, Alfred Lord. In Memoriam, 1850. Print.

Ujević, Tin. Izabrana djela Tina Ujevića [Selected Works of Tin Ujević], 8 vols. Ed. Bože Čović. Zagreb: August Cesarec, 1986. Print.

Yates, Frances. Giordano Bruno and the Hermetic Tradiuton. London: Routledge \& Kegan Paul, 1964. Print.

---. The Art of Memory. London: Routledge \& Kegan Paul, 1966. Print.

\section{Web}

'Down by the Salley Gardens'. Wikipedia.com. Wikipedia. n.d. Web. 17 Jun 2011.

Honey, H. C. A Turkish-English Dictionary. Oxford: Oxford University Press, 1976 [1947]. Web.

Kermode, Frank. 2010. 'Eliot and the Shudder'. The London Review of Books, 32/9. pp 13-16.

Web. 17 Jun 2011.

Oxford English Dictionary online. 2011 edition. Web. 17 Jun 2011.

'Tin Ujević'. Wikipedia.com. Wikipedia. n.d. Web. 15 Jun 2011.

Ujević, Tin. 2005. Some poems in Croatian, with English. Trans. Richard Berengarten and Daša Marić. South Slavic Literature Library. Ed. Borut Maričić. Web. 14 Jun 2011.

---. 2010. Some poems in Croatian, with English. Trans. Richard Berengarten and Daša Marić. Mediterranean Poetry. 2010. Ed. Anders Dahlgren. Web. 14 June 2011. 
[1] In the English-speaking world, so far as I know, there has been only one international event to honour Tin. It took place at the Bowery Poetry Club, New York, on April 21, 2007. Entitled Homage to Tin Ujević, it was organised by Marylin Cvijić. Among the readers was the American poet Anne Waldman. Translations by Daša Marić and myself were included. The event was covered by the evening news programme (Dnevnik) on Croatian TV, April 22, 2007.

[2] Salley Gardens: Gort na Saileán. “'Salley' or 'sally' is a form of the Standard English word 'sallow', i.e., a tree of the genus Salix. It is close in sound to the Irish word saileach, meaning willow." http://en.wikipedia.org/wiki/Down_by_the_Salley_Gardens, accessed 17 June 2011.

[3] For insightful explorations of 'form', see Leighton 2007 and Hass 1984. My notes are in-formed by these works.

[4] My deployment of this term follows that of Ricks (1974) vis-a-vis Keats and English Romanticism.

[5] I intend 'purity' in the way that Donald Davie (1952) uses the term.

[6] Croatian writer of fiction, poetry and criticism, 1873-1914.

[7] The term imagem, at first coined in the context of my own poetics, is deployed here to indicate 'a bundle or nexus of integrated or correlated images'. It is delineated more fully later.

[8] See Kermode 2010.

[9] See note 7 above.

[10] Shortly after arriving at this term, together with this first, tentative definition, I discovered that it already exists as a word - in Portuguese - meaning, simply, 'image'. In English, though, I think the coinage imagem helpful, because it fills a conceptual gap, comparable to the word mythologem (meaning 'unit of myth or mythology', or, as defined by the OED online, 'fundamental theme or motif of myth or other discourse').

[11] The only contemporary Anglophone poet I know whose imagems touch and sometimes sustain this quality and range of synaesthetic tessitura is Robert Hass. See for example, The Apple Trees at Olema (2010). 
[12] Yates 1964 \& 1966.

[13] The term "implicate order" derives from Bohm (1980) and is deployed here in the sense in which he uses it.

[14] Tomislav Kuzmanović: email 18/6/11.

[15] Both in this sentence and subsequently, the term 'conceit' means a "a fanciful, ingenious or witty notion or expression" (Oxford English Dictionary 499).

[16] The last line of this quotation provides the title to this essay, which I gratefully acknowledge here.

[17] In 'Cool Park and Ballylee,' 1931, Yeats 276

\section{c) ()요}

Creative Commons Attribution-NonCommercial-NoDerivatives 4.0 International License 